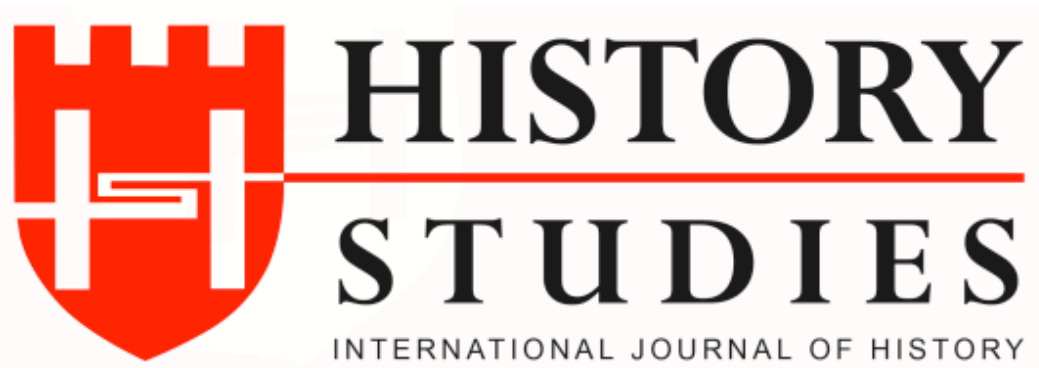

ISSN: 13094173 (Online) 1309 - 4688 (Print)

Volume 9 Issue 4, p. 139-156, November 2017

DOI: 10.9737/hist.2017.554

\title{
Türk Demokrasi Tarihinde Olağan Dışı Sürece Bir Örnek: Birinci Nihat Erim Hükümeti'nin Kuruluşu
}

An Example to the Extraordinary Process in Turkish Democracy History: Foundation of the First Nihat Erim Government

\author{
Dr. Mustafa SALEP \\ (ORCID: 0000-0001-6560-7629) \\ Să̆lık Bakanlı̆̆
}

Öz: Íkinci Dünya Savaşı'nda demokratik devletlerin elde etmiş oldukları başarı, Türkiye üzerinde etkili olmuş ve 1945 yılında ikinci bir siyasi partinin kurulması sağlanmıştır. Böylece, Türkiye'de çok partili siyasal hayat resmen ve fiilen başlamıştır. 1946 yılında kurulan Demokrat Parti (DP), 1950 seçimlerinde Cumhuriyet Halk Partisi (CHP) karşısında büyük bir başarı elde ederek tek başına iktidara gelmiştir. 10 yll tek başına iktidarda kalan Demokrat Parti, 27 Mayls 1960 tarihli askeri darbe ile yönetimden uzaklaştırllmıştır. 1961 seçimlerinden sonra Türkiye için koalisyonlu yıllar başlamış, bu durum 1965 yılına kadar devam etmiştir. 1965 seçimlerinde tek başına iktidara gelen Adalet Partisi ise, 12 Mart 1971 Muhtırasına kadar iktidarda kalmıştır. 27 Mayıs'tan sonra 12 Mart Muhtırası, Türk demokrasisine vurulan ikinci darbe niteliğindedir. Çünkü seçimle iktidara gelen Demirel Hükümeti, istifa etmek zorunda kalmıştır. Bu arada partisinden istifa eden CHP Kocaeli Milletvekili Nihat Erim, başbakan olarak atanmıştır. Nihat Erim, çoğunluğu Meclis dışından olmak üzere parti üyelerinin de içinde bulunduğu yeni bir hükümet kurmuştur. 12 Mart Muhtırasında öngörülen reformların gerçekleştirilmesi amacıyla kurulan Erim Hükümeti, Meclis'ten güvenoyu alarak faaliyetlerine başlamıştır. Muhtıranın gölgesinde kurulan bu hükümet, zorunlu görülen icraatları yapma gayreti içerisinde olmuştur. Bu makalede, demokrasinin çıkmaza girdiği bir süreçte I. Nihat Erim Hükümeti'nin kuruluşu değerlendirilmiștir.

Anahtar Kelimeler: Nihat Erim, Demokrasi, 12 Mart Muhtırası, Türk Silahlı Kuvvetleri, Meclis.

\begin{abstract}
The success of the democratic states in the Second World War had affected Turkey and resulted in the formation of a second political party. Therefore, the multi-party system has started officially and practically in Turkey. In the 1950 elections, the Democrat Party (DP), which was established in 1946, has gained a huge success against Republican People's Party (RPP) and came the power alone. The Democrat Party had stayed in power alone for 10 years and had been driven away from administration with a coup d'état dated 27 May 1960. After the 1961 elections, the coalition government years for Turkey had started and this situation had continued until the year of 1965. The Justice Party, which came to power alone in 1965 elections, stayed in power until 12 March 1971 Memorandum. After the $27^{\text {th }}$ May coup, 12th March Memorandum is like a second strike to the Turkish democracy. Because Demirel Government, which came to power via elections, had to resign. Meanwhile, RPP Koceali Deputy Nihat Erim had been assigned as Prime Minister. Nihat Erim had formed a new government consisting of members mostly outside of the National Assembly including the party members. The Erim Government, which was formed to realize the foreseen reforms in $12^{\text {th }}$ March Memorandum, had started its activities by receiving vote of confidence from the Turkish Grand National Assembly. This government formed under the shadow of the Memorandum was on the prowl of the practices that were seen compulsory. In this article, First Nihat Erim Government is evaluated during the process when the democracy reaches deadlock.
\end{abstract}

Keywords: Nihat Erim, Democracy, $12^{\text {th }}$ March Memorandum, Turkish Armed Forces, Turkish Grand National Assembly. 


\section{Giriş}

Türkiye'nin siyasi tarihinde hükümetlerin kuruluşları ve icraatları yakından takip edilmiştir. Meşrutiyet tecrübesinden sonra 23 Nisan 1920'de açılan Birinci Büyük Millet Meclisi ile hükümet sistemi, yeni kurulan Türkiye'nin en önemli yönetim usulü olmuştur. Cumhuriyetin ilanından sonra rejimin adı da belirlenmiş ve millet egemenliğine dayanan bir model ortaya konulmuştur. Bu rejimde millet, seçimle temsilcilerini meclise göndermekte ve hükümetin oluşumuna katkı sağlamaktadır. Temsili demokrasi de denilen bu sistem ile meclise giren milletvekilleri içerisinden hükümet üyeleri belirlenmektedir.

Demokrasinin en önemli unsurlarından birisi hiç şüphesiz siyasi partilerdir. Yeni Türkiye'nin kurulmasından sonra çok partili siyasi hayata geçme çabaları bir müddet devam etmiştir. Cumhuriyet Halk Partisi'nin kuruluşundan sonra iki kez denenen ikinci parti kurma girişimi sonuçsuz kalmıştır. İkinci Dünya Savaşı ile birlikte demokratik devletlerin savaşta başarı elde etmesi, Türkiye'de yeni siyasi partilerin kuruluşunu kolaylaştırmıştır. Bu çerçevede, 1945 'te kurulan Milli Kalkınma Partisi ile çok partili siyasi hayat resmen başlamıştır. 1950 seçimlerine kadar bu partiyi diğer partilerin kuruluşu takip etmiştir. Nihayet 1950 seçimlerinde iktidar, 1946 yılında kurulmuş olan Demokrat Parti’ye geçmiştir.

Demokrat Parti'nin 27 Mayıs 1960 tarihli askeri darbe ile iktidardan uzaklaştırılması, Türkiye'de demokrasinin gelişimi açısından olumsuz bir gelişme olmuştur. 1961'den 1965 yılına kadar ülkede, koalisyonlu yıllar hüküm sürmüştür. 1965 yılında yapılan genel seçimlerde Adalet Partisi tek başına iktidara gelmiş ve 12 Mart 1971 tarihine kadar iktidarda kalmıştır. 12 Mart Muhtırası ile askerler, hükümete bazı uyarılarda bulunmuşlar ve yerine getirilmesini istedikleri reformların yapılmaması durumunda fiilen iktidarı ele geçireceklerini açıklamışlardır. 12 Mart Muhtırası ile Başbakan Süleyman Demirel ve hükümet üyeleri istifalarını vermek zorunda kalmışlardır. Başbakan Süleyman Demirel, 12 Mart 1971 tarihli istifa mektubunda şunları belirtmiştir: "Genelkurmay Başkanı ve Kuvvet Kumandanları tarafindan Zatı devletlerine, Cumhuriyet Senatosu ve Millet Meclisi Başkanlarına tevdi edilip bugün Türkiye Radyolarının saat 13.00 bülteninde Türk kamuoyuna duyurulan muhtıranın Anayasa ve hukuk devleti anlayışı ile telifini mümkün görmediğimizden Hükümetin istifa kararı aldığını saygı ile arz ederim ${ }^{1} . "$ Burada Başbakan Demirel, askerlerle karşı karşıya gelmemek amacıyla hükümetten çekilmek zorunda kalmış, buna mukabil muhtıranın hukuki olmadığını ifade etmiştir. Seçimle iktidara gelmiş bir hükümetin baskı sonucunda hükümetten ayrılması demokratik açıdan doğru bir yöntem olmamakla birlikte, muhtıraya hukuki açıdan eleştiri getirilmiş olması dönemin koşulları değerlendirildiğinde olumlu bir gelişme sayılabilir.

\section{Nihat Erim'in Hükümeti Kurmakla Görevlendirilmesi}

12 Mart Muhtırasından sonra Demirel Hükümetinin istifası, yeni hükümet arayışlarını başlatmıştır. Komuta kademesinin ortak imzasıyla ilan edilen muhtıra, ordu içerisinde bazı subayların tasfiyesini de beraberinde getirmiştir. Bu çerçevede 16 Mart 1971'de beş general, bir amiral ve 35 albay emekliye sevk edilmiştir. Emekliye sevk işlemleri Türk Silahlı Kuvvetleri'nde bazı sıkıntıların olduğuna işaret sayılabilir. Emekli edilenlerden bazılarının 12 Mart'tan önce askeri müdahaleye niyetlenmiş olan subaylardan oluşması, bu sıkıntının

${ }^{1}$ Resmi Gazete, 13 Mart 1971, Sayı: 13777, s. 2. 
kuvvetli bir delilidir ${ }^{2}$. Ordu içerisinde yaşanan bu durum, Türkiye'nin siyasi atmosferini de etkilemiş ve kurulacak hükümet de bu etkiden nasibini almıștır.

Demirel Hükümetinin istifasından sonra Cumhurbaşkanı Cevdet Sunay, siyasi partilere birer mektup göndererek yeni hükümetle ilgili görüşlerini sormuştur. Siyasi partiler, Cumhurbaşkanı Sunay'a görüşlerini ulaştırmışlar, koalisyon veya seçim konusunda karar kıldıklarını belirtmişlerdir ${ }^{3}$. Cumhuriyet Halk Partisi (CHP) Genel Başkanı İsmet İnönü, kurulacak reformcu hükümeti destekleyeceklerini belirtmiş, Adalet Partisi (AP) de kurulacak hükümete destek verileceğini açıklamıştır ${ }^{4}$. Demokratik Parti Divanı da, 17 Mart 1971'de Cumhurbaşkanı Cevdet Sunay'a sunduğu mektupta demokratik nizamın vazgeçilmezliğine işaret etmiş, Anayasa ve hukuk devleti anlayışı içerisinde kurulacak olan hükümete yardımcı olunacağ 1 vurgulanmıştır ${ }^{5}$. Cumhuriyet Senatosu Kontenjan Grubu Başkanı Cemal Madanoğlu ise, mutlak tarafsız bir başbakanın kendilerince destekleneceğini belirtmiştir ${ }^{6}$.

Türkiye'deki siyasi gelişmeler, yabancı basın tarafından dikkatle takip edilmiştir. $\mathrm{Bu}$ çerçevede Alfred Friendly, 17 Mart 1971 tarihli yazısında Türkiye'de 12 Mart sonrasında dört siyasi parti liderinin prensip olarak koalisyon konusunda anlaştıklarını ve başbakanlığa da tarafsız birisinin getirilmesinin kararlaştırıldığını belirtmiş, bütün bunların askeri müdahale olasılığını yumuşattığını savunmuştur. $\mathrm{Bu}$ süreçte Demirel Hükümetinin yerine gelecek olanların "güçlü ve saygın bir hükümet" kurarak Türkiye'deki anarşiyi bitirmesinin beklendiğini nakletmiştir?.

Siyasi partilerin yeni dönemle ilgili Cumhurbaşkanlı̆̆ına ilettikleri görüşlerden sonra Cumhurbaşkanı Genel Sekreteri Cihat Alpan, 19 Mart 1971'de CHP Kocaeli Milletvekili Prof. Dr. Nihat Erim'e bir mektup göndermiştir ${ }^{8}$. Bu mektupta Alpan, Cumhurbaşkanının kendisini partiler üstü bir anlayışla Başbakan olarak görevlendirmek istediğini ve bunu kabul etmesi durumunda CHP'den istifa etmesi gerektiğini belirtmiştir'. Bu konuyu Nihat Erim, Sadi

Koçaş'ın İsmet İnönü ile görüşmesini istemiştir. İsmet İnönü ise, Nihat Erim'in teklifi kabul etmesi durumunda CHP'den istifa edeceğini öğrenmiş ve bunu CHP Parti Meclisi'nin kabul etmeyeceğini ve bir daha politika yapamayacağını düşünerek reddetmesini talep etmiştir. Ancak, bir gün sonra sırayla Kemal Satır ve Nihat Erim, İsmet İnönü ile görüşerek CHP'den istifaya dair izni almışlardır ${ }^{10}$. Nihayet CHP Kocaeli Milletvekili Nihat Erim, 19 Mart 1971'de Cumhurbaşkanı Cevdet Sunay tarafından hükümeti kurmakla görevlendirilmiştir ${ }^{11}$.

\section{Nihat Erim'in Yeni Hükümeti Kurma Mücadelesi}

\footnotetext{
${ }^{2}$ Ali Gevgilili, Yükseliş ve Düşüş, Bağlam Yayınları, İstanbul 1987, s. 523; Sadi Koçaş, 12 Mart Anıları, Tomurcuk Matbaas1, İstanbul 1978, s. 56; Feroz Ahmad, Demokrasi Sürecinde Türkiye (1945-1980), Türkçeleştiren: Ahmet Fethi, 4. Bask1, Hil Yayınları, İstanbul 2010, s. 359; Hürriyet Gazetesi, 17 Mart 1971, s. 1.

${ }^{3}$ Hürriyet Gazetesi, 17 Mart 1971, s. 1; Son Havadis Gazetesi, 17 Mart 1971, s. 1.

${ }^{4}$ Cumhuriyet Gazetesi, 17 Mart 1971, s. 1.

${ }^{5}$ Demokratik Parti, 72 'ler Hareketi ve Demokratik Parti, Demokratik Parti Yayınları, Ankara 1971, s. 156- 157.

${ }^{6}$ Cumhuriyet Gazetesi, 18 Mart 1971, s. 1.

${ }^{7}$ New York Times, Mar 17, 1971; Turkish parties plan a coalition. New York Times (1923-Current File), pp. 1. Retrieved from http://search.proquest.com/docview/119151347?accountid=9645

${ }^{8} 1946$ seçimlerinden sonra milletvekili olarak siyasete giren Nihat Erim, aynı zamanda bir hukukçu olarak 28 Haziran 1957'de İnsan Hakları Komisyonu üyeliğine seçilmiş̧ir. Ayrıntılı bilgi için bkz. Başbakanlık Cumhuriyet Arşivi (BCA), Dosya: P, Fon Kodu: 030.01 Yer No: 128.829.7.

${ }^{9}$ Adalet Partisi, Oniki Mart ve Sonrası, Cilt: 1, AP Genel Merkez Yayınları No: 41, Ayyıldız Matbaası, Ankara 1971, s. 25.

${ }^{10}$ Anılarında Sadi Koçaş, 12 Mart 1971'den önce Nihat Erim'le yaptığı konuşmayı nakletmiştir. Koçaş, Erim'e zor şartlarda başbakanlık teklifi alması durumunda ne cevap vereceğini sormuştur. Erim de şartlara bağlı olduğunu vurgulamıștır. Ayrıntılı bilgi için bkz. Koçaş, age, s. 22-24, 57- 59.

${ }^{11}$ Cumhuriyet Gazetesi, 20 Mart 1971, s. 1.
} 
Cumhurbaşkanı Cevdet Sunay, Nihat Erim'i hükümeti kurmakla görevlendirdiği gün, 19 Mart 1971 tarihinde siyasi parti liderlerine de bir mektup göndermiştir. Sunay, bu mektubunda partiler üstü bir anlayışla Kocaeli Milletvekili Nihat Erim'in başbakanlığında kurulacak olan hükümete "herhangi bir şart ileri sürmeden" iştirak edilmesini ve güvenoyuna mazhar kılınmasını istemiştir. Sunay ayrıca, kurulacak hükümetin görevlerini yerine getirmesi konusunda desteklenmesini talep etmiştir ${ }^{12}$. Cumhurbaşkanının bu mektubuna karşılık Demokratik Parti Genel Başkanı Ferruh Bozbeyli, 19 Mart 1971'de TRT'nin 20.45 haber bülteninde yayınlanan beyanatıyla cevap vermiştir. Bozbeyli, Demokratik Parti'nin demokratik nizamın vazgeçilmezliğine inandığını ve "şartsız bir evet" isteğine uymayacaklarını belirtmiştir ${ }^{13}$. Bu durum, dönemin şartları açısından değerlendirildiğinde demokrasi tarihimiz açısından önemlidir.

Nihat Erim'in hükümeti kurmakla görevlendirilmesi yabancı basın tarafından asker sivil ilişkileri bağlamında değerlendirilmiştir. Times'ın 20 Mart 1971 tarihli sayısında, parlamentodan Prof. Dr. Nihat Erim'in başbakan olarak seçildiği ve askerin denetimi altında demokrasi için ilk adımın atıldığ 1 vurgulanmıştır ${ }^{14}$. Alfred Friendly ise, 19 Mart 1971 tarihli haberinde askeri liderlerin Demirel'in gecikmiş reformları konusunda kızgın olduklarını ve zayıf duruşundan rahatsız olduklarını savunmuştur ${ }^{15}$. Yine Alfred Friendly’nin 21 Mart 1971 tarihinde vermiş olduğu bilgilerde, Demirel'in istifasıyla ortaya çıkan siyasi krizin, Nihat Erim'in açıklanmasından sonra çözüldüğü belirtilmiştir. Friendly, Erim'in nazik ve saygılı bir hukuk profesörü olduğunu belirtmiş, reformist bir hükümete dair söz verdiğini ancak, temel reformların gerçekleştirilmesinin zor olduğunu savunmuştur ${ }^{16}$.

Hükümeti kurmakla görevlendirilen Kocaeli Milletvekili Nihat Erim, ortada fevkalade bir durum olduğunu belirtmiş ve milli bir hükümet kuracağını vurgulamıştır ${ }^{17}$. Bu arada Nihat Erim, partilerle görüşmelere başlamış ve partilerin hükümete katılmalarını istemiştir. Erim, yeni hükümetin öncelikli vazifesinin memleketin rahat yaşanır bir memleket haline tekrar dönmesini sağlamak olduğunu belirtmiştir ${ }^{18}$. Nihat Erim, sonraki günlerde yaptığı açıklamada reform tasarılarını eski plancıların hazırlayacağını vurgulayarak, hükümete güven duyulmasını istemiştir $^{19}$. Bu süreçte yaşananları anısında nakleden Sadi Koçaş, I. Erim Hükümetini kurma çalışmaları sırasında ve sonrasında bazı kişilerin Türkiye Büyük Millet Meclisi (TBMM)'nin kapatılmasını ve siyasi faaliyetlere uzun bir süre izin verilmemesini istediklerini belirtmiştir. Koçaş, bu teklifleri hiç dikkate almadıklarını ve TBMM'yi sürekli açık tutmanın gayreti içerisinde olduklarını vurgulamıştır ${ }^{20}$. Meclisin sıkıntılı dönemlerde açık tutulması, bu süreçte demokrasinin daha da çıkmaza girmesini engellediği savunulabilir.

\footnotetext{
${ }^{12}$ Süleyman Demirel, 1971 Buhranı ve Aydınlı̆̆a Doğru, Doğuş Matbaası, Ankara 1973, s. 10; Adalet Partisi, age, s. 27; Demokratik Parti, age, s. 161; Cumhuriyet Gazetesi, 20 Mart 1971, s. 1.

${ }^{13}$ Demokratik Parti, age, s. 163.

${ }^{14}$ The Times, Mar 20, 1971, p. 5;

http://0find.galegroup.com.seyhan.library.boun.edu.tr/ttda/infomark.do?\&source=gale\&prodId=TTDA\&userGroup Name=bogazici\&tabID $=$ T003\&docPage $=$ article\&searchType $=$ BasicSearchForm\&docId $=$ CS84898932\&type $=$ multi page \& contentSet $=$ LTO\&version $=1.0$

${ }^{15}$ New York Times, Mar 20, 1971; New York Times (1923-Current File), pp. 3. Retrieved from $\mathrm{http} / / /$ search.proquest.com/docview/119391794?accountid=9645

${ }^{16}$ New York Times, Mar 21, 1971; New York Times (1923-Current File), pp. 1. Retrieved from http://search.proquest.com/docview/119189297?accountid=9645

${ }^{17}$ Hürriyet Gazetesi, 20 Mart 1971, s. 1.

${ }^{18}$ Cumhuriyet Gazetesi, 21 Mart 1971, s. 1.

${ }^{19}$ Cumhuriyet Gazetesi, 24 Mart 1971, s. 1.

${ }^{20}$ Koçaş, age, s. $98-99$.
} 
Şevket Süreyya Aydemir de, hükümet kurma çalışmalarıyla ilgili değerlendirmelerde bulunmuş ve en büyük tehlikenin zayıf bir hükümetin kurulma ihtimali olduğunu belirtmiştir. Aydemir, bu süreçte yeni bir seçimin hem kentlerde hem de köylerde askeri müdahaleyi hoş görmeyen ve ona karşı tahrik edilen kesimleri, gerici örgütlerin etrafında toplayacağını savunmuştur ${ }^{21}$. Bu durum, basının hükümet kurma çalışmaları sırasında siyasi temsilcileri etkileme eğiliminde olduğunu göstermektedir. 12 Mart öncesinde gerçekleştirilmiş olan seçimlerin ve seçmen tercihlerinin bu kapsamda değerlendirilmesi yeni hükümet kurma çalışmalarının anlaşılmasını kolaylaştırabilir² ${ }^{22}$.

Nihat Erim'in hükümeti kurma görevinden sonra hem siyasi partiler hem basın hem de çeşitli sivil toplum örgütleri görüşlerini açıklamışlardır. Bu bağlamda Sosyal Demokrasi Dernekleri Federasyonu'nun 4. Genel Kurulunda söz alan konuşmacılar, yeni hükümete karşı çıkmışlar ve yeni hükümetin sosyal demokrat gelişmeyi önlemek için kurulacağını savunmuşlardır. Diğer taraftan Türk-İş Genel Başkanı Seyfi Demirsoy, Nihat Erim başkanlığında kurulacak hükümete destek olduklarını açıklamıştır ${ }^{23}$. Bu da Erim başkanlığında kurulacak olan hükümetin bazı kesimler tarafından destekleneceğini bazı kesimler tarafından ise desteklenmeyeceğini göstermektedir.

Cumhurbaşkanının Erim başkanlığındaki hükümetin koşulsuz desteğine karşı çıkan Demokratik Parti Divanı, 22 Mart 1971 tarihli tebliği ile kuvvetli bir murakabe müessesesinin kurulamayacağı inancıyla Nihat Erim hükümetine katılmayacaklarını duyurmuştur ${ }^{24}$. Nihayet Demokratik Parti, bu hükümete güvenoyu vermemiş̧tir. Ferruh Bozbeyli, 12 Mart sonrasında Nihat Erim'e; "Siz partiler üstü değil partiler dışısınız. Hiçbir partinin rızası yok." dediğini belirtmiştir ${ }^{25}$. Demokratik Parti'nin olumsuz görüşüne karşı1lı CHP ortak grubu ağılıklı olarak, İsmet İnönü'nün hükümeti destekleme görüşünü benimsemiş ve yeni hükümete katılma kararında olduğunu açıklamıştır ${ }^{26}$. Bu çerçevede, 21 Mart 1971 tarihinde CHP ortak grubunda Erim'in partiler üstü reform hükümetine üye verilmesi, 45'e karşı 100 oyla kabul edilmiştir ${ }^{27}$. Olumsuz oyun fazlalığı, CHP içerisindeki muhalefetin derinliğini göstermesi bakımından önemlidir.

${ }^{21}$ Şevket Süreyya Aydemir, “En Büyük Tehlike: Zayıf Hükümet!”, Cumhuriyet Gazetesi, 22 Mart 1971, s. 2.

${ }^{22}$ Bu kapsamda; 1961 y1lı milletvekili genel seçimlerinde 28.2711.000 nüfusun \% 45.2'si yani 12.925.395'inin seçmen olarak kayıtlı olduğu anlaşılmaktadır. Bu sayının \% 81.41'i olan 10.522.716 kişi 1961 seçimlerinde oy kullanmıştır. 1965 seçimlerine ise katılım oranı ortalama \% 71.26 oranında gerçekleşmiş̧ir. 1965 genel seçimlerinde AP \% 52.9, CHP ise \% 28.7 oranında oy almıştır. 12 Ekim 1969 seçimlerine gelindiğinde, katılım oranı \% 64.35 olarak gerçekleşmiştir. 12 Ekim 1969 seçimlerinde AP oyların \% 46.5'ini ve 256 milletvekilini, CHP oyların 27.4'ünü ve 143 milletvekilini, GP oyların \% 6.6'sını ve 15 milletvekilini, MP oyların 3.2'sini ve 6 milletvekilini, MHP oyların \% 3'ünü ve 1 milletvekilini, BP oyların \% 2.8'ini ve 8 milletvekilini, TíP oyların \% 2.68'ini ve 2 milletvekilini, YTP oyların \% 2.2'sini ve 6 milletvekilini, bağımsızlar ise oyların \% 5.6'sını ve 13 milletvekilliği kazanmıştır. Bu seçim sonuçları, özellikle 1965 ve 1969 seçimlerinde AP'nin diğer partilere göre daha başarılı olduğunu göstermektedir. Ayrıntılı bilgi için bkz. Devlet İstatistik Enstitüsü, 1950- 1965 Milletvekili ve 1961, 1964 Cumhuriyet Senatosu Üye Seçimleri Sonuçlarl, Devlet İstatistik Enstitüsü Yayını No: 513, Ankara 1966, s. V; Resmi Gazete, 17 Kasım 1961, Sayı: 10960, s. 5833; Nermin Abadan, Anayasa Hukuku ve Siyasi Bilimler Açısından 1965 Seçimlerinin Tahlili, Ankara Üniversitesi Siyasal Bilgiler Fakültesi Yayını, Sevinç Matbaası, Ankara 1966, s. 364; Sadettin Bilgiç, Türkiye'de Seçimler ve Seçim Kanunları, Boğaziçi Yayınları, İstanbul 1995, s. 10- 11; Cumhuriyet Halk Partisi, CHP XX. Kurultayl Parti Meclisi Raporu (3 Temmuz 1970),Ulus Basımevi, Ankara 1970, s. 18; Tevfik Çavdar, Türkiye'nin Demokrasi Tarihi (1950- 1995), İmge Kitabevi Yayınları, Ankara 1996, s. 157, 161- 162; Gevgilili, age, s. 435- 436; Cumhuriyet Gazetesi, 16 Ekim 1961, s. 1; Son Havadis Gazetesi, 14 Ekim 1969, s. 1; Son Havadis Gazetesi, 15 Ekim 1969, s. 1; Hürriyet Gazetesi, 15 Ekim 1969, s. 1.

${ }^{23}$ Cumhuriyet Gazetesi, 21 Mart 1971, s. 1.

${ }^{24}$ Demokratik Parti, age, s. 164; Hürriyet Gazetesi, 22 Mart 1971, s. 1.

${ }^{25}$ Ferruh Bozbeyli, Yalnız Demokrat, Hazırlayanlar: İhsan Dağı- Fatih Uğur, Timaş Yayınları, İstanbul 2009, s. 337.

${ }^{26}$ Cumhuriyet Gazetesi, 22 Mart 1971, s. 1.

${ }^{27}$ Gevgilili, Yükseliş ve Düşüş, s. 524. 
Adalet Partisi Senato ve Meclis Gruplar1 ise 22 Mart 1971'de yeni kurulacak olan hükümete üye vermeye dair ortak bir karar almış ve hükümet programını gördükten sonra bu kararı tekrar değerlendirme yönünde bir karar almıştır ${ }^{28}$. AP Genel Başkanı Süleyman Demirel, 22 Mart 1971'de AP Meclis Grubunda yapmış olduğu konuşmada, AP'nin hür demokratik nizama inancını belirtmiş ve yapılanların hürriyetçi nizamı yaşatmak için olduğunu savunmuştur ${ }^{29}$. Demirel'in ve AP'nin bu süreçteki genel eğilimine baktığımızda, sert bir politika yerine daha yumuşak bir politika seçtiğini görüyoruz.

AP Genel Başkanı Süleyman Demirel, 23 Mart 1971'de ise TRT'nin sorularını cevaplamıştır. Memleketin bir buhran içinde olduğunu belirten Demirel; "Buhran bir hükümet buhranını aşan büyük bir rejim Anayasa buhranıdır” demiştir. Konuşmasına devamla Demirel, Nihat Erim tarafından kurulacak olan partiler üstü hükümete üye vermeye karar verdiklerini belirtmiş ve memleketin uzun süre hükümetsiz kalmasını istemediklerini ifade etmiştir ${ }^{30} .12$ Mart'la Türk Devleti'nin zincir halkalarında kopukluk meydana geldiğini belirten Demirel, bütün gayretin kopan zinciri yeni baştan meydana getirmeye çalışmak olduğunu ifade etmiştir. Demirel, silahlı kuvvetlerin 12 Mart fiili durumu ile emrinde bulunduğu parlamentonun ve hükümetin emrinden çıktığını belirtmiştir. Hürriyetçi demokrasinin işler hale gelmesi için, kopan zinciri maharetle tekrar yerine koymak için çalıştıklarını vurgulamıştır ${ }^{31}$. Bu durum, AP'nin ve liderinin demokraside açılan yaranın derinleştirilmemesine çalışacaklarını göstermektedir.

$\mathrm{Bu}$ arada, Cumhurbaşkanı Cevdet Sunay tarafından yeni Bakanlar Kurulunu oluşturmak üzere başbakan olarak görevlendirilen Kocaeli Milletvekili Prof. Dr. Nihat Erim ${ }^{32}$, kabine listesini oluşturmaya başlamıştır. Bu süreçte Nihat Erim'in bakanlıklar konusunda Sadi Koçaş'la aktif çalıştı̆̆ 1 ve yapılan birçok görüşmeyi Koçaş'ın gerçekleştirdiği anlaşılmaktadır. Nihayet Koçaş, anılarında listede yer alması için birkaç ismi Erim'e bildirdiğini nakletmiştir ${ }^{33}$. Nihat Erim, Koçaş'ın ısrarla dışişleri bakanlığını kabul etmesini istemiş, Koçaş ise bunu kabul etmemiştir. Diğer bakanlıklarda da Erim, Koçaş'a geniş salahiyet vermiş ve birinci derecede yakınında olmasını istemiştir ${ }^{34}$.

Nihat Erim'in Bakanlar Kurulunu oluştururken baskı altında kaldığı anlaşılmaktadır ${ }^{35}$. Erim'e yakınlığı ile tanınan Koçaş, anılarında Cumhurbaşkanlığının, Genelkurmay Başkanlığının ve MİT'in hükümet oluşturulmasında etkili olduğunu ve bazı adayların hükümete girmesini istemediklerini belirtmiş̧ir. Nihayet Cumhurbaşkanı Cevdet Sunay, Erim Kabinesinde 27 Mayısçıları istemediğini belirtmiş ve bu nedenle Sadi Koçaş, Sunay'la bir görüşme gerçekleştirmiştir. Koçaş ise, 27 Mayısçıların kabineye alınmasında 1srarcı olmuş ve en sonunda sadece Mehmet Özgüneş'in kabineye alınabileceğini belirtmiştir ${ }^{36}$. Genelkurmay Başkanı Memduh Tağmaç da, 24 Mart 1971 tarihinde telefon ederek, hükümetin durumu hakkında bilgi istemiştir. Nihayet Başbakanla görüşen Tağmaç, asker bakana taraftar olmadıklarını vurgulamıştır ${ }^{37}$. Türk- İş de kendi istedikleri kişinin Çalışma Bakanlığı için

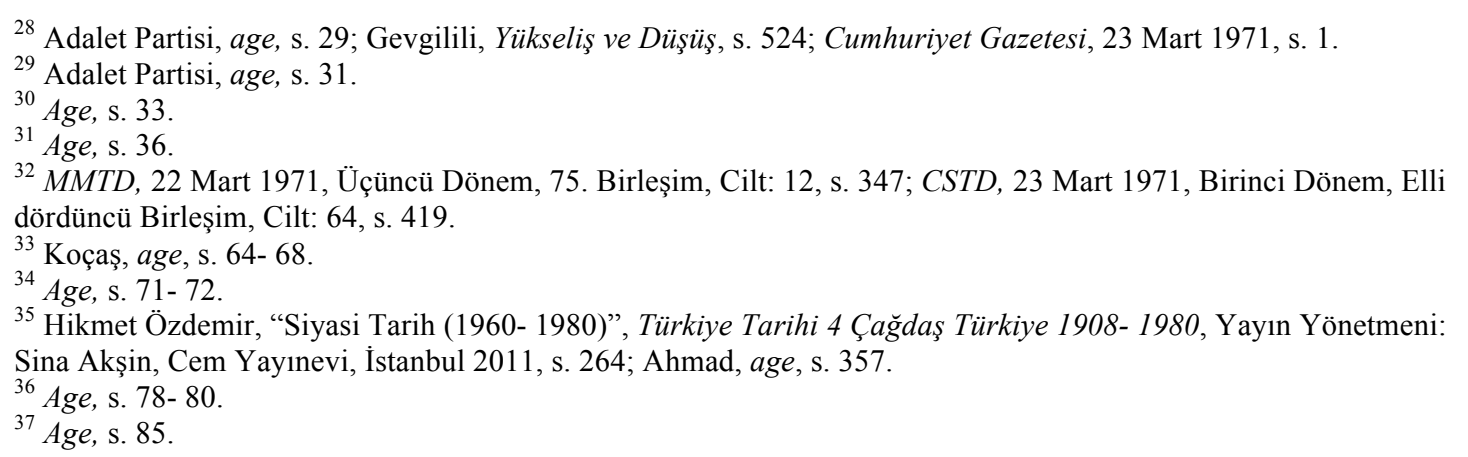

${ }^{28}$ Adalet Partisi, age, s. 29; Gevgilili, Yükseliş ve Düşüş, s. 524; Cumhuriyet Gazetesi, 23 Mart 1971, s. 1.

Adalet Partisi, age, s. 31

31 .

${ }^{32}$ MMTD, 22 Mart 1971, Üçüncü Dönem, 75. Birleşim, Cilt: 12, s. 347; CSTD, 23 Mart 1971, Birinci Dönem, Elli dördüncü Birlesim, Cilt: 64, s. 419.

Sina Akşin, Cem Yayınevi, İstanbul 2011, s. 264; Ahmad, age, s. 357.

${ }^{37}$ Age, s. 85. 
görevlendirilmesini talep etmiştir. Bu süreçte Genel Sekreter Halil Tunç, Sadi Koçaş'1 arayarak istedikleri kişinin Erim Kabinesinde olmaması durumunda hükümetin grevden başını alamayacağı iddiasında bulunmuştur ${ }^{38}$. Bütün bu bilgiler, hükümetin kuruluş sürecinde Nihat Erim' in asker ve sivil birçok kesimin baskısı altında kaldığını göstermektedir.

\section{I. Nihat Erim Hükümeti’nin Kurulması}

Nihat Erim tarafından yeni hükümetin kuruluş çalışmaları tamamlanmıştır. Cumhurbaşkanı Cevdet Sunay tarafından atanan Bakanlar Kurulu, 26 Mart 1971'de Millet Meclisi'ne sunulmuş ve resmen görevine başlamıştır ${ }^{39}$. Buna göre; Başbakanlığa Bağımsız Kocaeli Milletvekili Prof. Dr. Nihat Erim, Başbakan Yardımcılığına CHP Konya Milletvekili Sadi Koçaş ve Dünya Bankası Ekonomi Uzmanı Attila Karaosmanoğlu, Devlet Bakanlığına Tabii Senatör Mehmet Özgüneş ve AP Samsun Milletvekili Doğan Kitaplı, Adalet Bakanlığına CHP İstanbul Milletvekili İsmail Arar, Milli Savunma Bakanlığına MGP Cumhuriyet Senatosu Van Üyesi Ferid Melen, İçişleri Bakanlığına Danıştay Üyesi (Eski Vali) Hamdi Ömeroğlu, Dışişleri Bakanlığına Büyükelçi Osman Olcay, Maliye Bakanlığına Maliye Bakanlığı Eski Müsteşarı ve Kurucu Meclis Üyesi Sait Naci Ergin, Milli Eğitim Bakanlığına Devlet Planlama Teşkilatı Eski Müsteşarı ve Büyükelçi Şinasi Orel, Bayındırlık Bakanlığına AP Zonguldak Milletvekili Cahit Karakaş, Dış Ekonomik İlişkiler Bakanlığına OYAK Yönetim Kurulu Üyesi Özer Derbil, Sağlık ve Sosyal Yardım Bakanlığına Ankara Üniversitesi Tıp Fakültesi Öğretim Üyesi Prof. Dr. Türkan Akyol, Gümrük ve Tekel Bakanlığına AP Niğde Milletvekili Haydar Özalp, Tarım Bakanlığına İstanbul İktisadi ve Ticari İlimler Özel Yüksek Okulu Müdürü Prof. Dr. M. Orhan Dikmen, Ulaştırma Bakanlığına Ulaştırma Bakanlığı Müsteşarı Haluk Arık, Çalışma Bakanlığına Ankara Barosu Başkanı Atila Sav, Sanayi ve Ticaret Bakanlığına Yüksek Mühendis Ayhan Çilingiroğlu, Enerji ve Tabii Kaynaklar Bakanlığına CHP Cumhuriyet Senatosu Giresun Üyesi İhsan Topaloğlu, Turizm ve Tanıtma Bakanlığına AP Rize Milletvekili Erol Yılmaz Akçal, İmar ve İskan Bakanlığına Başbakanlık Yükssek Denetleme Kurulu Üyesi Selahattin Babüroğlu, Köy İşleri Bakanlığına Tokat Eski Milletvekili Dr. Cevdet Aykan, Orman Bakanlığına İstanbul Üniversitesi Orman Fakültesi Öğretim Üyesi Prof. Dr. Selahattin İnan, Gençlik ve Spor Bakanlığına AP Konya Milletvekili Sezai Ergun atanmıştır ${ }^{40}$.

Nihat Erim'in ilk kabinesi, ağırlıklı olarak TBMM dışından belirlenmiştir ${ }^{41}$. Bu kabinede; 5 üye AP'den, 3 üye CHP'den, 1 üye MGP'den, 1 üye Cumhuriyet Senatosu Milli Birlik Grubundan ve 14 üye ise parlamento dişındaki teknisyenlerden ve uzmanlardan oluşturulmuştur ${ }^{42}$. Demokratik Parti ise Nihat Erim kabinesine üye vermemiştir ${ }^{43}$. Hükümeti kurma sürecinde Nihat Erim'e yardım eden Sadi Koçaş, Dışişleri Bakanlığg teklifini kabul etmemiş, bunu daha bilgili ve dünyayı tanıyan birisinin yapması gerektiğini belirtmiştir. Nihayet Erim, başbakan yardımcısı olmayı Koçaş'a teklif etmiş ve kabul ettirmiştir ${ }^{44}$.

Nihat Erim, hükümeti Süleyman Demirel'den teslim almıştır. Atanan yeni kabine ilk toplantısını aynı gün saat $17.45^{\prime}$ te yapmış ve reformların gerçekleştirileceğini vurgulamıştır. Bu toplantıda Başbakan Erim, partili bakanların parti disiplininden ayrılmalarını istemiş ve kurulmuş olan kabinenin sorumluluklarının partilerde olmayacağını ve görev alanlarda

\footnotetext{
${ }^{38}$ Age, s. 82.

${ }^{39}$ MMTD, 26 Mart 1971, Üçüncü Dönem, 78. Birleșim, Cilt: 12, s. 382- 383.

${ }^{40}$ MMTD, 26 Mart 1971, Üçüncü Dönem, 78. Birleşim, Cilt: 12, s. 383;

https://www.tbmm.gov.tr/hukumetler/HB33.htm

${ }^{41}$ Çavdar, age, s. 197- 198.

${ }^{42}$ Cumhuriyet Gazetesi, 27 Mart 1971, s. 1; Gevgilili, Yükseliş ve Düşüş, s. 524- 525.

${ }^{43}$ Bozbeyli, age, s. 341.

${ }^{44}$ Koçaş, age, s. 59- 62.
} 
olacağını vurgulamıştır ${ }^{45}$. Bu durum, kabinede her ne kadar partili üyeler olsa da partilerin sorumluluk üstlenmeyeceğine işaret sayılabilir.

Nihat Erim'in kabineye üye tespitinde asker ve sivil çeşitli gruplardan etkilendiğini söylemiștik. Bunun dıșında yabancıların tesiri olduğu da savunulmuştur. Bu çerçevede Nihat Erim'in Dünya Bankası'nda çalışmakta olan Attila Karaosmanoğlu hakkında MíT'in solcu olduğu iddiasıyla olumsuz kanaat belirtmesi üzerine ABD'de savunma bakanlığı yapmış olan McNamara'dan Karaosmanoğlu'nun kabineye alınıp alınmayacağını sorduğu iddia edilmiştir ${ }^{46}$. $\mathrm{Bu}$ iddiaya ihtiyatla yaklaşmak gerekmiş olsa dahi, Erim Hükümetinin hangi usullerle kurulduğunu göstermesi bakımından önemli bir ipucudur. Bilindiği üzere 1970'li yıllarda Türkiye'nin en önemli sorunlarından birisi ekonomidir. Bu nedenle Nihat Erim, hükümetini ağırlıklı olarak ekonomi uzmanlarından oluşturma gayreti içerisinde olmuştur ${ }^{47}$. Hükümetin oluşturulması üzerine AP Genel Başkanı Süleyman Demirel'in Nihat Erim'e AP tarafindan önerilen isimlerin değil de başka isimlerin kabinede yer alması konusunu sorduğu ve Erim'in de; "Ben zaten haysiyetli bir işin içinde değilim." dediği nakledilmiştir ${ }^{48}$.

$\mathrm{Bu}$ arada Bakanlar Kurulu listesi, 30 Mart 1971 tarihinde Cumhuriyet Senatosu'nda okunmuştur. Kabinenin 14 üyesinin parlamento dişından belirlenmesi, kabineye teknokrat bir ağırlık kazandırılmak istendiğini göstermektedir ${ }^{49}$. Konuyla ilgili olarak Demokratik Parti Genel Başkanı Ferruh Bozbeyli, 12 Mart sonrasında kurulan hükümete siyasi partilerden katılanların parti terbiyesi içerisinde ve halkı tanıyan insanlar olduklarını belirtmiştir. Buna mukabil, parti dışından gelenlerin "sanki milleti adam etmeye" gelmiş ve milletin amiriymiş gibi bir havaya girdiklerini savunmuştur ${ }^{50}$. Bu durum, dikkatleri parti dışından hükümete giren üyeler üzerine yoğunlaştırmıştır.

Erim Hükümeti göreve başladıktan sonra ilk Milli Güvenlik Kurulu toplantısına 27 Mart 1971'de katılmıştır ${ }^{51}$. Kara Kuvvetleri Komutanı Orgeneral Faruk Gürler de, Başbakan Nihat Erim'i makamında ziyaret ederek görevinde başarı dilemiştir ${ }^{52}$. Bu durum, Erim'i iktidara getirmiş olan Silahlı Kuvvetlerin onu destekleyeceği şeklinde yorumlanabilir ${ }^{53}$. Yeni hükümetin kurulması ile birçok kurumda müsteşar ve genel müdür seviyesinde önemli değişiklikler yapılacağı söylenmiştir ${ }^{54}$. Bu durum kamuoyunda bir beklentinin olduğunu göstermektedir. $\mathrm{Bu}$ çerçevede Erim Hükümetinin görevinin zor olduğu anlaşılmaktadır.

\footnotetext{
${ }^{45}$ Hürriyet Gazetesi, 27 Mart 1971, s. 1; Koçaş, age, s. 89.

${ }^{46}$ Çetin Yetkin, Türkiye'de Askeri Darbeler ve Amerika, Yeniden Anadolu ve Rumeli Müdafaa-i Hukuk Yayınları, Antalya 2010, s. 169.

${ }^{47}$ Türkiye'yi 12 Mart sürecine götüren sebepler arasında ülkenin içinde bulunduğu sosyal ve ekonomik sorunların olduğunu söyleyebiliriz. Ağırlıklı olarak 1968- 1971 yılları arasında hükümeti oldukça zor duruma sokan öğrenci olaylarını, ideolojik sebeplerden önce ülkenin içinde bulunduğu sosyo-ekonomik koşullar açısından değerlendirmek gerekmektedir. Nihayet 12 Mart Muhtırasında da ülkenin sosyal ve ekonomik huzursuzluklarına işaret edilmiştir. 12 Mart Muhtırası ile birlikte Başbakan Demirel'in istifa etmesi üzerine başbakan olarak görevlendirilen Nihat Erim, toplumsal huzursuzluğu ortadan kaldırmak amacıyla ekonomi uzmanlarından yararlanmak istemiştir. Erim bu politikası ile olağan dışı bir süreci başarılı bir şekilde geçirmeyi arzulamıştır. Ali Gevgilili, Türkiye'de 1971 Rejimi, Milliyet Yayınları, İstanbul 1973, s. 236- 237.

${ }^{48}$ Cüneyt Arcayürek, Çankaya (1923-1980), Cilt 1, Yeni Gün Yayıncılık Cumhuriyet Kitapları, İstanbul 2010, s. 216.

${ }^{49}$ CSTD, 30 Mart 1971, Birinci Dönem, Elli altıncı Birleşim, Cilt: 64, s. 493.

${ }^{50}$ Bozbeyli, age, s. 340.

${ }^{51}$ Cumhuriyet Gazetesi, 28 Mart 1971, s. 1.

${ }^{52}$ Hürriyet Gazetesi, 29 Mart 1971, s. 1.

${ }_{53}$ Metin Toker, Solda ve Sağda Vuruşanlar, Akis Yayınları, Ankara 1971, s. 88.

${ }^{54}$ Hürriyet Gazetesi, 28 Mart 1971, s. 1.
} 
Nihayet denilebilir ki, 1lımlı reformculardan hızlı devrimcilere kadar çeşitli gruplar, Erim Hükümetinden çok şey beklemektedirler ${ }^{55}$.

Türkiye Ziraat Mühendisleri Birliği Genel Kurulunda konuşan Başbakan Yardımcısı Sadi Koçaş, hükümetin işbaşına geliş sebebi olarak bir takım reformların yapılabilmesini sağlamak olduğunu belirtmiştir. Koçaş, reformların ya yapılacağını ya da uzun süre iktidarda kalınmayacağını vurgulamıştır. Türkiye İşveren Sendikaları Konfederasyonu Başkanı Halil Kaya ise, yapmış olduğu basın toplantısında yeni hükümetin huzuru bir an önce sağlaması ve iktisadi hayatta da istikrarı temin etmesini istediklerini belirtmiştir. Üniversite Asistanları Sendikası da yayınlamış olduğu bildiride, yeni kabineye bazı önerilerde bulunmuştur. Meclis'te Demirel ve kardeşlerine ait yolsuzluk iddialarının araştırılmasını ve eski hükümetten hesap sorulmasını talep etmişlerdir ${ }^{56}$.

İlhan Selçuk ise, Erim Hükümetiyle ilgili yaptığı değerlendirmede, en önemli işin polisin tarafsızlaştırılması olduğunu belirtmiştir. Selçuk’a göre AP Hükümeti, kendisine karşı gelen polisleri ve emniyet görevlilerini geri plana itmiştir. Sürülen ve sindirilen emniyet görevlilerinin tekrar görevlerine dönmeleri ve emniyet teşkilatında tesis edilecek adaletin Erim Hükümetinin ilk görevi olması gerektiğini savunmuştur ${ }^{57}$. Bütün bunlar, çeşitli toplumsal kesimlerin yeni hükümetten farklı taleplerinin olduğunu göstermektedir.

\section{I. Nihat Erim Hükümeti’nin Programı ve Güven Oylaması}

Nihat Erim'in başbakanlığında kurulan ve görevine başlayan yeni hükümet, program üzerine yoğunlaşmıştır. Bu çerçevede programın hazırlanmasında ilgili bakanlıklardan çeşitli konularda bilgiler talep edilmiştir. Bakanlıklardan gelen yaklaşık 200 sayfalık metin 20 sayfaya kadar düşürülerek I. Erim Hükümetinin Programı hazırlanmıştır. Bu programın hazırlanması sürecinde Başbakan Yardımcısı Sadi Koçaş ve Attila Karaosmanoğlu aktif olarak çalışmışlardır ${ }^{58}$. Bu bilgiler, yeni hükümete ait programın bütün bakanlıkların katkısı ile hazırlandığını göstermektedir.

Başbakan Nihat Erim, yeni hükümete ait programı 2 Nisan 1971'de Millet Meclisi'nde okumuştur. Erim, programın zorunlu reformları gerçekleştirmeye yönelik bir program olduğunu belirtmiş ve hükümetin de "Reform Hükümeti" olarak ortaya çıktığını vurgulamıştır ${ }^{59}$. Erim'in hükümet programında özellikle 12 Mart'ta eleştirilen konulara değinilmiş ve 1961 Anayasası'nın gösterdiği doğrultuda yapılması zorunlu reformların hiç beklenmeden gerçekleştirilmesinin amaçlandığg belirtilmiştir $^{60}$.

Başbakan Erim, yeni hükümete ait programda; Atatürk ilkelerinin ve devrimlerinin tüm olarak uygulanması, idari ve ekonomik yapının modernleştirilmesi, sosyal adaletin gerçekleştirilmesi konusunda kararlı adımlar atılması, bugünkü huzursuzluk ve asayişsizliğin hızla giderilmesi, ekonomik ve siyasal bağımsızlık içinde kalkınma olanaklarının hızla hazırlanması, laiklik ilkesinin tam olarak uygulanması, öğretim birliğinin sağlanması, devlet kesiminin etkin bir şekilde çalışır hale getirilmesi, özel kesimin toplum yararına uygun bir çalışma düzenine, güvenlik ve kararlılık içinde kalkınmaya katkıda bulunması, gelir dağılımını düzeltecek vergi, bütçe, kredi ve başkaca tedbirlerin alınması, kooperatifçiliğin gelişmesini sağlayacak tedbirlerin alınması, eğitimde fırsat eşitliğinin gerçekleştirilmesi, sağlık, sosyal

\footnotetext{
${ }^{55}$ Nadir Nadi, "Güç Görev”, Cumhuriyet Gazetesi, 28 Mart 1971, s. 1.

${ }^{56}$ Cumhuriyet Gazetesi, 29 Mart 1971, s. 1.

${ }^{57}$ İlhan Selçuk, "İlk şart...", Cumhuriyet Gazetesi, 30 Mart 1971, s. 2.

${ }^{58}$ Koçaş, age, s. 92- 93.

${ }^{59}$ MMTD, 2 Nisan 1971, Üçüncü Dönem, 80. Birleşim, Cilt: 12, s. 393.

${ }^{60}$ Çavdar, age, s. 198- 199.
} 
yardım ve başkaca kamu hizmetlerinin yaygınlaştırılması ve bunlardan yararlanmada eşitliğin sağlanması, gençliğin temel sorunlarının ele alınması gibi konulara değinmiş ve hükümetin temel ilkelerini belirtmiştir ${ }^{61}$.

Başbakan Erim, yeni hükümete ait programda ön planda yapmaya kararlı oldukları reformları da sıralamıştır. Buna göre; Toprak ve tarım reformu, milli eğitim reformu, mali reformlar, hukuk ve adalet reformu, devlet kesiminin yeniden düzenlenmesi, enerji ve tabii kaynaklarla ilgili reformlar öncelikli gerçekleştirilmesi planlanan reformlar şeklinde sıralanmıştır ${ }^{62}$. Hükümet böylece toplumsal sıkıntıların giderilmesini kendisine hedef göstermiştir.

Başbakan Nihat Erim, hükümet programını 2 Nisan 1971'de aynı zamanda Cumhuriyet Senatosu'nda okumuştur ${ }^{63}$. Reformların hiç bekletilmeksizin gerçekleştirilmesine dikkat çeken Erim, bu nedenle hükümetlerine "Reform Hükümeti" adını verdiklerini burada da belirtmiştir. Hükümet programında her bakanlığın yapacağı işlerin ayrı ayrı programda yer almayacağını belirten Erim, sadece ana ilkelerin belirtileceğini vurgulamıştır. Reform için ana ilkelere vurgu yapmıştır. Buna göre; Atatürk ilkelerinin ve devrimlerinin tüm olarak uygulanması, idari ve ekonomik yapının modernleştirilmesi, sosyal adaletin gerçekleştirilmesi konusunda kararlı adımlar atılması, bugünkü huzursuzluk ve asayişsizliğin hızla giderilmesi ana ilkeler arasında sayılmıştır ${ }^{64}$.

Başbakan Erim, hükümet programının kısa ve uzun vadeli hedeflerini belirli bir stratejide gerçekleştirmeyi amaçladıklarını belirtmiştir. İlk altı aylık dönemde daha önceden hazırlıkları belirli bir olgunluğa erişen ancak, gerçekleştirilemeyen toprak reformu, eğitim reformu ve mali reformların daha uzun süreli reformların ilk adımı olacağını vurgulamıştır. Bu ilk dönemde sonraki dönemlerle ilgili hazırlıkların yapılacağını belirten Erim, Üçüncü Beş Yıllık Kalkınma Planı'nın hazırlanmasının da bu dönemde gerçekleștirileceğini belirtmiștir. Erim ayrıca, devlet kuruluşlarının reformcu bir yapıya kavuşturulmasının önemine değinmiştir ${ }^{65}$. Erim'in bahsettiği bu konulardan, ülke ekonomisinin iyileştirilmesine yönelik bir programın hükümet tarafından yürütülmek istendiği anlaşılmaktadır.

Başbakan Erim, hükümet programında hukuk ve adalet reformu konusundan bahsederken suç ve suçlunun ortadan kaldırılmasında öncelikle suçu doğuran sosyal ve ekonomik nedenlerin ve bunalımların giderilmesi gerektiğini belirtmiştir. Bunun yanında son zamanlarda yaşanan olaylara değinen Erim, silahlı saldırılar, adam kaçırma ve tedhişçilik gibi olayların daha etkili müeyyidelere bağlanması gerektiğini vurgulamıştır. Vatandaşların huzurunu, can ve mal emniyetini sağlamak için kanunların uygulanacağını ve kanunların yetersizliğinin tespit edilmesi durumunda yüce heyetin huzuruna geleceklerini ifade etmiştir ${ }^{66}$. Erim, ülkenin bozulan güvenlik ve asayişinin, vatandaşların huzurunun ve devlet itibarının korunacağını ve güvenlik kuvvetlerine karşı sarsılan saygının bir an önce sağlanacağını belirtmiştir ${ }^{67}$. Nihayet Erim, huzur ve güvene vurgu yaparak şunları söylemiştir: "Kanunların pervasızca çiğnendiği bir Devlete gerçek anlamıyla Devlet denemez. Türk Ulusu güçlü ve düzenli devletler kurmasını ve sürdürmesini tarihin her çağında bilmiş bir ulustur. Türkiye'yi bölmek isteyenlere firsat verilmeyecektir. Yurdumuzu Atatürk ülküsünden saptırarak, sağ ya da sol bir

\footnotetext{
${ }^{61}$ MMTD, 2 Nisan 1971, s. 394; Hürriyet Gazetesi, 3 Nisan 1971, s. 1.

${ }^{62}$ MMTD, 2 Nisan 1971, s. 395.

${ }^{63}$ CSTD, 2 Nisan 1971, Birinci Dönem, Elli yedinci Birleşim, Cilt: 64, s. 499.

${ }^{64}$ CSTD, 2 Nisan 1971, s. 500; Cumhuriyet Gazetesi, 3 Nisan 1971, s. 1.

${ }^{65}$ CSTD, 2 Nisan 1971, s. 501.

${ }^{66}$ CSTD, 2 Nisan 1971, s. 503.

${ }^{67}$ CSTD, 2 Nisan 1971, s. 504.
} 
diktatoryanın ve anarşinin kucağına asla ve asla düşürmemek Hükümetimizin en başta güdeceği amaçtır ${ }^{68}$."

Nihat Erim'in meclislerde okumuş olduğu hükümet programından sonra programla ilgili değerlendirmelere geçilmiştir. Hükümet programı hakkında CHP adına konuşan Genel Başkan İsmet İnönü, 1960 askeri müdahalesinin milletçe kabul edildiğini ve 12 Mart 1971 Muhtırasının da aynı şekilde milletçe kabul edildiğini savunmuştur ${ }^{69}$. İsmet İnönü, Nihat Erim'in kurmuş olduğu hükümetin bir koalisyon hükümeti olmadığını belirtmiş ve bütün icraatından kendisinin mesul olduğunu ifade etmiştir. İnönü, partilerin hiçbirisinin hükümetin sorumluluğuna katılmadığını ve hükümetin icraatlarının Meclis'in tam bir denetimi altında olduğunu belirtmiştir ${ }^{70}$. İsmet İnönü ayrıca, hükümete oy vermek mecburiyetinde olduklarını ve her şeyden evvel ordunun müdahaleye mecbur bırakılmaması için partiler üzerindeki vebalin büyük olduğunu ifade etmiştir. Erim Hükümetinin iyi niyetle kurulmuş bir hükümet olduğunu belirten İnönü, partilerin bu hükümete güvenoyu vererek memleketi maceraya sürüklememeleri gerektiğini savunmuştur ${ }^{71}$. İnönü'nün bu açıklamaları, kendi parti milletvekili iken istifa eden Nihat Erim'in CHP tarafından destekleneceğini göstermektedir.

Milli Güven Partisi adına konuşan Turhan Feyzioğlu da, Nihat Erim Hükümetinin bir koalisyon hükümeti olmadığını ve buhranlı bir dönemin özel şartları içinde kurulmuş bir hükümet olduğunu belirtmiştir. Feyzioğlu, Milli Güven Partisi olarak Erim Hükümetine güvenoyu verme kararı aldıklarını ve bunda; "memleketi içinde bulunduğu dar geçitten selamet yoluna çıkarma düşüncesinin" etkili olduğunu belirtmiştir ${ }^{72}$. Feyzioğlu da bu açıklamaları ile sıkıntılı sürecin derinleşmemesi gerektiğini vurgulamıştır.

Demokratik Parti adına konuşan Talat Asal ise, Erim Hükümetinin oluşturulma şekline dikkat çekmiş ve teknisyenlerden müteşekkil bir hükümetin siyasi sorumluluk alamayacağını belirtmiştir. Asal, bakanlık makamının siyasi bir makam olduğunu belirtmiş ve hükümetin de yine parlamento içerisinden seçilmesinin daha doğru olacağını vurgulamıştır. Erim Hükümetine ait programdaki eksikliklere dikkat çeken Asal, 60 bin yerleşim yerinde elektrik yokken her köye televizyon getirileceğinden bahsedildiğini; sağlık, imar, iskan, bayındırlık, gümrük, tekel, ihracat ve yurt dışındaki işçi meselelerinden birer kelimeyle de olsa bahsedilmemiş olmasının programdaki eksikliklere birer işaret olduğunu belirtmiştir ${ }^{73}$.

Adalet Partisi grubu adına konuşan Orhan Dengiz ise, egemenliğin kayıtsız ve şartsız millete ait olması ilkesine ters düşen tutum ve davranışların itibar görmesi halinde rejim buhranlarının kaçınılmaz hale geleceğini belirtmiş ve bunun uzun vadede memlekete büyük zararlar vereceğini vurgulamıştır. 1961 Anayasası'nın getirmiş olduğu hak ve hürriyetlerin anlayış ve uygulanışındaki farklı görüşlerin bu hakların kötüye kullanılmasını mümkün kıldığını belirten Dengiz, hükümet programındaki bazı reformların yapılması ile her şeyin yoluna gireceği inancına katılmadıklarını ifade etmiştir ${ }^{74}$. Rejim meselesini halletmek için bütün siyasi partilerin sorumluluk içinde davranması gerektiğini belirten Orhan Dengiz sözlerini şu şekilde tamamlamıştır: "Adalet Partisi olarak, aziz vatanımızı ve milletimizi her türlü badireden ve her türlü musibetten korumak için akliselim yolunda ve engin vatanperverlik duygusu içinde Anayasa değişikliğine varan her çeşit tedbirin alınmasına

\footnotetext{
${ }^{68}$ CSTD, 2 Nisan 1971, s. 508.

${ }^{69}$ MMTD, 5 Nisan 1971, Üçüncü Dönem, 81. Birleşim, Cilt: 12, s. 409.

${ }^{70}$ MMTD, 5 Nisan 1971, s. 410.

${ }^{71}$ MMTD, 5 Nisan 1971, s. 413.

${ }^{72}$ MMTD, 5 Nisan 1971, s. 413.

${ }^{73}$ MMTD, 5 Nisan 1971, s. 427- 429.

${ }^{74}$ MMTD, 5 Nisan 1971, s. 435- 436.
} 
taraftar olduğumuzu belirtmek isteriz ${ }^{75}$." 12 Mart Muhtırası ile en büyük uyarı hiç şüphesiz Adalet Partisi'ne yapılmıştır. Buna rağmen AP'nin yeni hükümete karşı olumsuz bir yaklaşım yerine yapıcı bir yaklaşım sergilediğini görmekteyiz.

Maraş Milletvekili İbrahim Öztürk ise, hükümet programı üzerine yapmış olduğu konuşmada 12 Mart'ın savunusunu yapmış ve şunları söylemiştir: "12 Mart Muhtırası ordu ile birlikte artık bizim malımız ve emanetimiz olmuştur. Biz onu takip etmezsek o, bizi takip edecektir. Esasen bizi takip eden, Anıttepe'de tüten manevi buhurdandır. Orada müspet ilim, özgürlük, kardeşlik, ilericilik ve laiklik ilkeleri tütmekte ve her gün bütün vatan ufuklarını sarsmaktadır. 12 Mart'ta bu ruhu aramak lazımdır ${ }^{76}$."

Cumhuriyet Senatosu'nda da Nihat Erim'in okumuş olduğu hükümet programı değerlendirilmiştir. AP Senato Grup Başkanvekili Balıkesir Senatörü Cemalettin İnkaya, 6 Nisan 1971'de AP grubu adına yaptığ 1 konuşmada, Adalet Partisi'nin demokratik rejimin geçirdiği buhran nedeniyle gönül kırıklığına uğradığını ifade etmiştir. İnkaya, fedakarlıklara parlamenter hukuk nizamının yaşatılması bahasına katlandıklarını belirtmiştir. İnkaya, Nihat Erim Hükümetinin programındaki; toprak ve tarım reformunu, milli eğitim reformunu, mali reformları, hukuk ve adalet reformunu, devlet kesiminin yeniden düzenlenmesini, enerji ve tabii kaynaklarla ilgili reformları parti olarak desteklediklerini açıklamıştır ${ }^{77}$.

Cumhuriyet Senatosu'nda CHP adına söz alan Hıfzı Oğuz Bekata, 1961 Anayasası'nın yeni umutlarla hazırlandığını ve bir demokrasi devrimini gerçekleştirme amacı güttüğünü belirtmiştir. Bekata, 1971 yılına geldiğinde Türkiye'nin manzarasını şu cümlelerle tasvir etmiştir: "1961 Anayasası ihmal edilmiştir. Memlekette ekonomik, sosyal ve siyasi denge büsbütün bozulmuştur. Can ve mal güvenliği, kanun hakimiyeti, itibarlı devlet ve Hükümet otoritesi ve siyasi istikrar kalmamıştır. İktidar sokağa, muhalefet sokağa, gençlik sokağa, memur sokağa, işçi sokağa dökülmüştür. Emniyet ve asayiş bozulmuş, memlekete husumet tohumları ekilmiş, umumi bir güvensizlik yurdu sarsmıştır. Hayat öylesine pahalılaşmıştır ki, iktisadi çöküntüyü sosyal sefalet izlemeye başlamıştır. Ve nihayet, sokakta kardeşin kardeşi öldürdüğü bir silahlı çatışma dönemine girilmiştir ${ }^{78}$."

Kontenjan Senatörü Cemal Madanoğlu da, Erim Hükümetiyle ilgili değerlendirmelerde bulunmuştur. Bu hükümetin Atatürkçü bir hükümet olacağını belirten Madanoğlu, hükümetin uygulamamak için direndiği Anayasayı uygulama, gelir dağılımını sağlama, ilerici eğitimi gerçekleştirme, ayrılıkçı sapkınların bölücü davranışlarını kırma, dinsel inançları politikanın yozlaştırıcı tekelinden kurtarma görevinin olduğunu belirtmiştir. Madanoğlu, Erim Hükümetinden sosyal ve hukuk devletini kurmasının istendiğini belirtmiştir. Madanoğlu ayrıca, Erim Hükümetinin Atatürkçü ve devrimci doğrultuda hükümet etmesi gerektiğini vurgulamıştır $^{79}$. Cemal Madanoğlu, Erim Hükümeti programına ait değerlendirmeler sırasında aşırı să̆ ve solla ilgili de şunları savunmuştur: "Aşırı sağ, aşırı sol; sorunu kanunun düşüncesini orta yola çekip yozlaştırmaktadır. Türkiye'nin gerçek sorunu Atatürkçülük, karşı Atatürkçülük, devrimcilik, karşı devrimcilik sorunudur. Orta yol sömürü yoludur. Aşıırı sağa da, aşırı sola da karşıyız diyenler bu bozuk düzeni savunduklarını artık anlamalıdırlar ${ }^{80}$."

Nihat Erim'in başbakanlığında kurulan hükümet programı, çeşitli kesimler ve kişiler tarafından farklı şekillerde yorumlanmıştır. Meclis dışından, alanında uzman kişilerin ağırlıklı

\footnotetext{
${ }^{75}$ MMTD, 5 Nisan 1971, s. 442- 443.

${ }^{76}$ MMTD, 5 Nisan 1971, s. 447.

${ }^{77}$ Adalet Partisi, age, s. 68- 70.

${ }^{78}$ CSTD, 6 Nisan 1971, Birinci Dönem, Elli sekizinci Birleşim, Cilt: 64, s. 512.

${ }^{79}$ CSTD, 6 Nisan 1971, Birinci Dönem, Elli sekizinci Birleşim, Cilt: 64, s. 523- 524.

${ }^{80}$ CSTD, 6 Nisan 1971, Birinci Dönem, Elli sekizinci Birleşim, Cilt: 64, s. 523.
} 
olduğu bu hükümetin hazırlamış olduğu program, büyük sanayi temsilcileri tarafından başarılı ve olumlu karşılanmıştır. Bu çerçevede İstanbul ve Ankara Sanayi Odası program hakkında olumlu fikir beyan etmiştir ${ }^{81}$. Bunda hükümet programının ağırlıklı olarak ekonomik konu içeriğine sahip olmasının etkili olduğu söylenebilir.

CHP Genel Başkanı İsmet İnönü, Meclis’te okunan Nihat Erim Hükümetine ait programla ilgili olarak "mükemmel bir program" yorumunu yapmıştır ${ }^{82}$. İnönü’nün hükümet programıyla ilgili bu değerlendirmesine karşılık Bülent Ecevit, programın 1961 yılından beri hazırlanmış olan programlar içerisinde en sönük, sulandırılmış, anlamsız ve boş bir hükümet programı olduğunu savunmuştur ${ }^{83}$. CHP ortak grubunda Erim Hükümetine güvenoyu verilmesi konusundaki görüşmelerde programa karşı çıkan Ecevit; "Parlamento yetkilerinin kısılmasını ve parlamentoya baskı yapılmasını kabul edecek miyiz?" diye sormuştur ${ }^{84}$. Bülent Ecevit'in hükümetle ve hükümet programıyla ilgili bu yaklaşımının Başbakan Nihat Erim'le arasındaki anlaşmazlıktan kaynaklandığı söylenebilir. Burada, 1965 yılından itibaren Bülent Ecevit'in liderliğini üstlendiği Ortanın Solu politikası kapsamında yaşanan gelişmelere bakmak gerekmektedir. 12 Mart Muhtırasından sonra muhtıraya herhangi bir tepki göstermeyen Bülent Ecevit, başbakan adayı olarak Nihat Erim'in açıklanmasından sonra tepki göstermeye başlamıştır. Bu süreçten itibaren her iki isim arasında ciddi bir rekabetin olduğu görülmektedir.

Hükümet programıla ilgili AP'den de bir açıklama gelmiştir. Yeni Asır gazetesine 3 Nisan 1971'de özel beyanat vermiş olan AP Genel Başkanı Süleyman Demirel, 12 Mart'tan sonra kurulmuş olan hükümetin koalisyon hükümeti olmadığını ve icraatından da hiçbir partinin sorumlu tutulamayacağını belirtmiştir. AP'nin hükümete üye vermesinin, AP'nin temel felsefesi ve programından fedakârlık edeceği anlamına gelmediğini vurgulamıştır ${ }^{85}$. Bu durum, siyasi partilerin Erim Hükümetiyle ilgili sorumluluk almak istemediklerini göstermektedir.

AP Genel Başkanı Süleyman Demirel, 6 Nisan 1971 tarihinde ise AP Meclis Grubunda

bir konuşma yapmıştır. Konuşmasında Demirel, 12 Mart sonrasında kurulan hükümete AP'den beş üyenin katıldığını ve bakan olduğunu belirtmiş̧tir. AP'li bakanların görevlerini yaparken eziklik hissetmemeleri gerektiğini belirten Demirel, onların hükümete AP grubunun kararıyla gittiklerini vurgulamıştır. Demirel ayrıca, partili milletvekillerine hükümette görev almış olan bakan arkadaşlarına her konuda destek olmalarını istemiştir ${ }^{86}$. Bu durum, kabinede görev yapacak olan AP'li bakanları rahatlattı̆̆ gibi parlamenter sistemin devamına da katkı sağlamıştır.

AP Meclis Grubu 6 Nisan 1971'de yaptığı toplantıda ayrıca, yeni kurulan hükümetin ortaya koyacağı her konunun grupta müzakere edildikten sonra karara bağlanmasına ve yeni hükümete güvenoyu verilmesine karar vermiştir. AP Meclis Grubu bu toplantıda şu kararları almıştır: "1- Kurulan yeni hükümetin bir koalisyon hükümeti olmaması, 2- Parlamenter demokratik rejimin bütün icapları ile devamı ve memleketin huzur ve istikrarının sağlanması, 3- Devlet ve rejimi temelinden yıkmaya yönelmiş teşebbüs ve hareketlerin karşısına milletin, parlamentonun ve bütün devlet müesseselerinin birlikte çıkma imkanlarının

\footnotetext{
${ }^{81}$ Gevgilili, Türkiye'de 1971 Rejimi, s. 249- 250.

${ }^{82}$ Cumhuriyet Gazetesi, 3 Nisan 1971, s. 1.

${ }^{83}$ Koçaş, age, s. 92- 93.

${ }^{84}$ Cumhuriyet Gazetesi, 4 Nisan 1971, s. 1.

${ }^{85}$ Adalet Partisi, age, s. 45.

${ }^{86}$ Age, s. 75.
} 
gerçekleştirilmesi ${ }^{87}$." Bütün bu bilgiler, AP'nin siyasi açıdan mağduriyete uğramış olsa da, mücadelesini hukuki ve olağan zeminde sürdürmek istediğini göstermektedir.

Nihat Erim Hükümetine ait 2 Nisan 1971 tarihli programı değerlendiren Türkiye İşçi Partisi (TIP) Senatörü Fatma Hikmet İșmen, hükümet programının AP hükümetlerinin uygulamış oldukları programların bir tekrarı olduğunu ve devamı olduğunu belirtmiştir. İşmen, Erim Hükümeti Programının da sanayi burjuvasının ihtiyaçlarını karşılamaya yönelik bir çalışma raporu olduğunu savunmuştur ${ }^{88}$. Buradan, hükümetlerin hazırlamış oldukları programların daha önceki hükümet programlarından esinlendiğini söyleyebiliriz.

Nihat Erim Hükümetine ait programın genel değerlendirmesinden sonra sıra güven oylamasına gelmiştir. Askeri etkinin kuvvetli olduğu bu dönemde siyasi partilerin, alacakları kararlarda bu etkiyi dikkate aldıkları anlaşılmaktadır. Nihat Erim Hükümetinin resmi olarak desteklenmesi anlamına gelen güven oylaması hakkında partiler, görüşlerini açıklamıştır. Yukarıda açıklandığı üzere CHP'nin büyük çoğunluğu Nihat Erim Hükümetini destekleme kararı almıştır. Milli Güven Partisi gruplarının yapmış oldukları toplantıda da, Erim Hükümetine güvenoyu verilmesi kararlaştırılmıştır ${ }^{89}$. AP de, Erim Hükümetini destekleme kararı almıştır. Bu destekle 1961 Anayasası'nda bir süredir değiştirilmesi istenip de yapılamayan değişikliklerin ordu eliyle yapılmasının istendiği belirtilmiştir ${ }^{90}$.

Nihayet, 2 Nisan'da okunan Nihat Erim Hükümeti Programına ve hükümete ait güven oylaması, 7 Nisan 1971 tarihinde Millet Meclisi'nde yapılmıştır. 370 kişinin katıldığ 1 güven oylamasında 321 üye kabul, 46 üye ret ve 3 üye de çekimser oy kullanmıştır. Böylece I. Nihat Erim Hükümetine, Millet Meclisi tarafından güvenoyu verilmiştir ${ }^{91}$. Adalet Partisi, I. Erim Hükümetine güvenoyu verilmesinden sonra 8 Nisan 1971'de teşkilata bilgi vermiştir. Burada, AP'nin yeni hükümetin kurulmasındaki ve yeni hükümete güvenoyu verilmesindeki maksadın genç demokrasiyi zedelenmiş olmaktan kurtararak, demokrasinin maruz kaldığı zararı telafi edebilme şeklinde bir değerlendirme yapılmıştır ${ }^{92}$. Sonuç olarak güven oylaması, 12 Mart Muhtırası ile çıkmaza giren demokrasimizin sonraki süreçte asli mecrasına kavuşması açısından önemli bir gelişme olmuştur.

\section{Sonuç}

Türk siyasi tarihinde I. Nihat Erim Hükümetinin kurulması süreci, önemli dönüm noktalarından birisi olmuştur. Bu hükümet, askerin 12 Mart Muhtırası ile bir önceki hükümeti uyardığı ve bu uyarı üzerine Başbakan Süleyman Demirel ve hükümet üyelerinin istifa etmek zorunda kaldığ 1 bir süreç neticesinde kurulmuş̧tur. Demokrasi ile yönetilen devletlerde milletin tercihi ve onayı dışında hükümetin düşürülmesi hiçbir zaman kabul görmemiştir. 27 Mayıs 1960 askeri darbesi, Türk demokrasi tarihinde antidemokratik sürecin ilk örneği sayılabilir. 12 Mart 1971 Muhtırası ise, tam bir askeri darbe niteliğinde olmasa da sonuçları itibariyle seçimle iktidara gelmiş olan bir hükümetin istifasına neden olmuştur. Muhtıra ile ortaya konulan taleplerin yerine getirilmemesi durumunda, fiili darbenin gerçekleştirileceği söylenerek siyaset kurumu ve parti liderleri baskı altına alınmıştır.

\footnotetext{
${ }^{87}$ Age, s. 83 .

${ }^{88}$ Fatma Hikmet İşmen, Parlamentoda 9 Yll, Çark Matbaası, Ankara 1976, s. 287.

${ }^{89}$ Hürriyet Gazetesi, 4 Nisan 1971, s. 1.

${ }^{90}$ Tanel Demirel, Adalet Partisi (İdeoloji ve Politika), İletişim Yayınları, İstanbul 2004, s. 247.

${ }^{91}$ MMTD, 7 Nisan 1971, Üçüncü Dönem, 82. Birleşim, Cilt: 12, s. 463; Gevgilili, Yükseliş ve Düşüş, s. 524- 525; Cavdar, age, s. 198.

${ }^{92}$ Adalet Partisi, age, s. 85.
} 
Muhtıradan sonra durumu değerlendiren Demirel Hükümeti, muhtıranın Anayasa ve hukuk devleti ilkeleriyle bağdaşmadığını belirterek istifa etmek zorunda kalmıştır. Savaşlar yanında içeride birçok sorunla mücadele eden bir millet, siyasi konularla yeterince ilgilenememiştir. Bununla birlikte, ülkemizin çok partili siyasal hayata geçişinden sonra milletin karşısına alternatif partiler çıkmaya başlamıştır. Demokrasinin vazgeçilmez bir unsuru olan seçimlerle tercihini ortaya koyan milletimiz, temsilcileri vasıtasıyla yönetimde söz sahibi olmaya başlamıştır. Bu süreçte Türk Milleti, ortaya çıkan sıkıntıları olgunluk içerisinde takip etmiştir. Özetle, imkanların yetersiz olduğu böyle buhranlı dönemlerde Türk Milleti, demokrasinin olgunlaşmasını ve gelişmesini sabırla beklemiştir.

Demirel Hükümetinin istifasından sonra CHP Kocaeli Milletvekili Nihat Erim'in partisinden ayrılmayı kabul etmesi üzerine yeni hükümeti kurmakla görevlendirilmesi, hükümet geleneğimizde ilk örnek sayılabilir. Nihat Erim'in CHP'den ayrılması sağlanarak, yeni hükümete partiler üstü bir kimlik kazandırılmak istenmiştir. Muhtıranın gölgesinde hükümet hazırlıklarını tamamlayan Nihat Erim, 14 üyesi meclis dışından olmak üzere hükümeti oluşturmuştur. Erim, bu süreçte başta ordu mensupları ve Cumhurbaşkanı olmak üzere çeşitli kesimlerin telkini ile karşı karşıya kalmıştır. I. Erim Hükümeti, 12 Mart Muhtırasında ortaya konulan reformların gerçekleştirilmesi amacıyla kurulmuştur. Bu nedenle I. Erim Hükümeti, "reform hükümeti” olarak da adlandırılmıştır.

I. Erim Hükümetine AP, CHP ve MGP üye vermiş olmakla birlikte, bu hükümetin

HISTORY STUDIES

153

Volume 9

Issue 4

November 2017 koalisyon hükümeti olarak değerlendirilmesi mümkün değildir. Zaten üye veren siyasi partiler de bu hükümetin koalisyon hükümeti olmadığını sıkça belirterek sorumluluk üstlenmeyeceklerini açıklamışlardır. Bu yönüyle I. Nihat Erim Hükümeti, dönemin koşullarında oluşturulan geçici ve nevi şahsına münhasır bir hükümet olmuştur. Toplumsal olayların oldukça yoğun olduğu bir dönemde iktidara gelen Nihat Erim ve hükümeti, beklentilerin karşılanması konusunda çalışmalarına başlamıştır. Hükümete ait programda da muhtırada belirtilen uyarılara özellikle vurgu yapıldığı anlaşılmaktadır. 19 Mart 1971 tarihinde hükümeti kurmakla görevlendirilen Nihat Erim, 2 Nisan 1971'de hükümet programını okumuştur. Nihayet 7 Nisan 1971'de yapılan güven oylaması ile I. Erim Hükümeti, 12 Mart Muhtırasından sonra kurulan ve güvenoyu alan ilk hükümet olmuştur. Sonuç olarak, demokrasinin buhranlı dönemlerinde başta siyasi partiler olmak üzere sivil toplum örgütleri ve özellikle milletin duruşu hayati derecede önemlidir. Demokrasinin yüksek standartlara kavuşması da hiç şüphesiz belirtilen kesimlerin demokrasiye sahip çıkmasına ve demokrasiyi geliştirmesine bağlıdır.

\section{KAYNAKÇA}

\section{Arşiv Belgesi ve Resmi Yayınlar}

Başbakanlık Cumhuriyet Arşivi (BCA), Dosya: P, Fon Kodu: 030.01 Yer No: 128.829.7.

Cumhuriyet Senatosu Tutanak Dergisi (CSTD), 23 Mart 1971, Birinci Dönem, Elli

dördüncü Birleşim, Cilt: 64 .

CSTD, 30 Mart 1971, Birinci Dönem, Elli altıncı Birleşim, Cilt: 64.

CSTD, 2 Nisan 1971, Birinci Dönem, Elli yedinci Birleşim, Cilt: 64.

CSTD, 6 Nisan 1971, Birinci Dönem, Elli sekizinci Birleşim, Cilt: 64.

Millet Meclisi Tutanak Dergisi (MMTD), 22 Mart 1971, Üçüncü Dönem, 75. Birleşim, 
Cilt:12.

MMTD, 26 Mart 1971, Üçüncü Dönem, 78. Birleşim, Cilt: 12.

MMTD, 2 Nisan 1971, Üçüncü Dönem, 80. Birleşim, Cilt: 12.

MMTD, 5 Nisan 1971, Üçüncü Dönem, 81. Birleşim, Cilt: 12.

MMTD, 7 Nisan 1971, Üçüncü Dönem, 82. Birleşim, Cilt: 12.

Resmi Gazete, 17 Kasım 1961, Sayı: 10960.

Resmi Gazete, 13 Mart 1971, Say1: 13777.

\section{Kitaplar, Hatıralar ve Siyasi Parti Yayınları}

ABADAN, Nermin, Anayasa Hukuku ve Siyasi Bilimler Açısından 1965 Seçimlerinin

Tahlili, Ankara Üniversitesi Siyasal Bilgiler Fakültesi Yayını, Sevinç Matbaası,

Ankara 1966.

ADALET PARTİSI, Oniki Mart ve Sonrası, Cilt: 1, AP Genel Merkez Yayınları No: 41, Ayyıldız Matbaası, Ankara 1971.

AHMAD, Feroz, Demokrasi Sürecinde Türkiye (1945-1980), Türkçeleştiren: Ahmet Fethi, 4. Bask1, Hil Yayınları, İstanbul 2010.

ARCAYÜREK, Cüneyt, Çankaya (1923-1980), Cilt 1, Yeni Gün Yayıncılık Cumhuriyet Kitapları, İstanbul 2010.

BİLGiç, Sadettin, Türkiye'de Seçimler ve Seçim Kanunları, Boğaziçi Yayınları, İstanbul 1995.

BOZBEYLİ, Ferruh, Yalnız Demokrat, Hazırlayanlar: İhsan Dağı- Fatih Uğur, Timaş

Yayınları, İstanbul 2009.

CUMHURIYET HALK PARTİSI, CHP XX. Kurultayl Parti Meclisi Raporu (3 Temmuz 1970),Ulus Basımevi, Ankara 1970.

ÇAVDAR, Tevfik, Türkiye'nin Demokrasi Tarihi (1950- 1995), İmge Kitabevi Yayınları, Ankara 1996.

DEMIREL, Süleyman, 1971 Buhranı ve Aydınlı̆̆a Doğru, Doğuş Matbaası, Ankara 1973.

DEMİREL, Tanel, Adalet Partisi (İdeoloji ve Politika), İletişim Yayınları, İstanbul 2004,

DEMOKRATIK PARTI, 72'ler Hareketi ve Demokratik Parti, Demokratik Parti Yayınları, Ankara 1971.

DEVLET İSTATİSTİK ENSTİTÜSÜ, 1950- 1965 Milletvekili ve 1961, 1964 Cumhuriyet Senatosu Üye Seçimleri Sonuçları, Devlet İstatistik Enstitüsü Yayını No: 513, Ankara 1966.

GEVGILIILİ, Ali, Yükseliş ve Düşüş, Bağlam Yayınları, İstanbul 1987.

Türkiye'de 1971 Rejimi, Milliyet Yayınları, İstanbul 1973. 
İŞMEN, Fatma Hikmet, Parlamentoda 9 Yıl, Çark Matbaası, Ankara 1976.

KOÇAŞ, Sadi, 12 Mart Anıları, Tomurcuk Matbaası, İstanbul 1978.

TOKER, Metin, Solda ve Sağda Vuruşanlar, Akis Yayınları, Ankara 1971.

YETKİN, Çetin, Türkiye'de Askeri Darbeler ve Amerika, Yeniden Anadolu ve Rumeli Müdafaa-i Hukuk Yayınları, Antalya 2010.

\section{Makaleler}

AYDEMİR, Şevket Süreyya, "En Büyük Tehlike: Zayıf Hükümet!”, Cumhuriyet Gazetesi, 22 Mart 1971, s. 2- 2.

NADİ, Nadir, “Güç Görev”, Cumhuriyet Gazetesi, 28 Mart 1971, s. 1 - 1.

ÖZDEMİR, Hikmet, "Siyasi Tarih (1960- 1980)", Türkiye Tarihi 4 Çăgdaş Türkiye 19081980, Yayın Yönetmeni: Sina Akşin, Cem Yayınevi, İstanbul 2011, s. 227- 292.

SELÇUK, İlhan, “İlk şart...”, Cumhuriyet Gazetesi, 30 Mart 1971, s. 2- 2.

\section{Süreli Yayınlar (Yerli ve Yabancı)}

Cumhuriyet Gazetesi, 16 Ekim 1961.

Cumhuriyet Gazetesi, 17 Mart 1971.

Cumhuriyet Gazetesi, 18 Mart 1971.

Cumhuriyet Gazetesi, 20 Mart 1971.

Cumhuriyet Gazetesi, 21 Mart 1971.

Cumhuriyet Gazetesi, 22 Mart 1971.

Cumhuriyet Gazetesi, 23 Mart 1971.

Cumhuriyet Gazetesi, 24 Mart 1971.

Cumhuriyet Gazetesi, 27 Mart 1971.

Cumhuriyet Gazetesi, 28 Mart 1971.

Cumhuriyet Gazetesi, 29 Mart 1971.

Cumhuriyet Gazetesi, 3 Nisan 1971.

Cumhuriyet Gazetesi, 4 Nisan 1971.

Hürriyet Gazetesi, 15 Ekim 1969.

Hürriyet Gazetesi, 17 Mart 1971.

Hürriyet Gazetesi, 20 Mart 1971.

Hürriyet Gazetesi, 22 Mart 1971.

Hürriyet Gazetesi, 27 Mart 1971.

Hürriyet Gazetesi, 28 Mart 1971.

Hürriyet Gazetesi, 29 Mart 1971.

Hürriyet Gazetesi, 3 Nisan 1971. 
Hürriyet Gazetesi, 4 Nisan 1971.

New York Times, Mar 17, 1971.

New York Times, Mar 20, 1971.

New York Times, Mar 21, 1971.

Son Havadis Gazetesi, 14 Ekim 1969.

Son Havadis Gazetesi, 15 Ekim 1969.

Son Havadis Gazetesi, 17 Mart 1971.

The Times, Mar 20, 1971.

\section{Internet Adresi}

https://www.tbmm.gov.tr/hukumetler/HB33.htm (Erişim Tarihi: 16 Mayıs 2017). 